\title{
Open Innovation in Indian Organizations: Types of Collaboration
}

\author{
Shiv S. Tripathi
}

\author{
" Exploration is the engine that drives innovation." \\ Innovation drives economic growth. So let's go \\ exploring.
}

\author{
Edith Widder \\ Oceanographer and marine biologist \\ Co-Founder and CEO of ORCA
}

\begin{abstract}
In order to succeed, it is important for any organization to leverage the power of the known and unknown networks around it. The organization must collaborate with others, and to do so requires it to open up its boundaries inside-out, outside-in, or both. However, the type of collaboration required to work with other parties and the respective output is different across different organizations on account of need, R\&D intensity, capability, and risk-taking ability, as well as the nature of the business and industry. The major problem that comes in the way of open innovation in Indian organizations is their risk taking ability; the more an organization collaborates, the more risk it is taking by sharing internal information with the other parties. Through a sample of 31 manufacturing-based firms in India belonging to 12 different industries, the article explores the types of collaborations that they have with various related or unrelated organizations as they engage in open innovation. The article compares the collaborations each industry has entered into to identify the industries that are more open to take risks by collaborating with other parties in multiple ways.
\end{abstract}

\section{Introduction}

India is a social country where people love to embrace other cultures and mix with them, but they tend to shy away in situations where there is a risk of failure (Badani, 2011). Organizations operating in India similarly are hesitant to share knowledge with other firms. The reasons for this behaviour are manifold but include a risk-averse culture, fear of loss of intellectual property, bureaucracy, and formal organizational structures that separate the old and established organizations from the new generation of more informal and agile small organizations. Old and established corporations often find it difficult to compete with the small and medium-sized specialized organizations who have access to better technology and resources. It is because of a revolutionary growth of startups in India in the recent years, partly due to the present government and its initiatives such as "Startup India" (startupindia.gov.in), "Skill India" (skillindia.gov.in), and "Make in India" (makeinindia.com), and partly due to the availability of funds through venture capitalists.
Innovation has been a buzzword in India for quite some time. Large organizations have realized that the growth mantra is to collaborate with other firms either to share the costs of $R \& D$ or to co-create newer products or technologies with small and medium-sized specialized companies. Indian companies now realize that there are several capability gaps that can be addressed by opening up the organizational boundaries for collaboration with other firms. Firm-to-firm collaboration is also a good starting point for risk-averse organizations because it motivates them to take larger risks in innovation.

Globally, there is a rich literature base available on the benefits of open innovation (Chesbrough, 2003) and its various forms (Gassmann \& Enkel, 2004), in addition to the pecuniary and non-pecuniary relationships among firms (Dahlander \& Gann, 2010). However, there is very little literature available on open innovation in India. At most, there are magazine articles and news reports that mention specific multinational and global companies 


\section{Open Innovation in Indian Organizations: Types of Collaboration}

\section{Shiv S. Tripathi}

announcing their open innovation programs in India. Indian organisations are still working in their "silos" and, despite government initiatives, they shy away from opening up their organizations, mainly due to the weak intellectual property regime in India. They fear that, if they open up, their intellectual property would be at risk or that its protection would require expensive and time-consuming cases in international forums. For example, despite liberal norms of outward foreign direct investment (OFDI) of up to $400 \%$ of the net worth of an organization, Indian companies are reluctant to invest abroad because the top management does not want to take risks. However, any innovation program cannot be successful unless it has the support of the top management and there is a structure for it in place. Looking at the positive side of it, there are certain organizations (including several in the present study) that inadvertently had to follow global norms to reach global exposure and found it easy to open up their organizational boundaries. Some leaders of large corporate houses in India have also started investing individually in ideas that in turn can give them potential advantages beyond revenue.

The present research examines the steps Indian manufacturing companies in different industries have taken towards open innovation by mapping the various types of collaboration they followed from among the possible types of collaboration that are possible between two manufacturing-based organizations (Box 1). Among the classification systems for open innovation, there is a system developed by Dahlander and Gann (2010) in which a collaborative activity can be classified into one of four categories of open innovation: i) inbound acquiring, ii) inbound sourcing, iii) outbound revealing, or iv) outbound selling. This system was selected for this research because it captures the nature and direction (i.e., inside-out versus outside-in) of the open innovation activities and was developed based on manufacturing alliances. Manufacturing firms are R\&D intensive and tend to require more resource-led collaboration with different parties compared to servicebased firms. Also, the complexity of operations of manufacturing firms, intellectual property regimes, market needs, and maturity of the ancillary industries and supporting infrastructure varies significantly from country to country; therefore, the nature of collaborations are also different in manufacturing-based firms.

Based on this premise, we set out to examine the types of open innovation and forms of collaboration used by 31 manufacturing-based firms in India. The purpose was to understand which industries are more tolerant
Box 1. Possible types of collaboration in open innovation with manufacturing-based firms

- university-industry collaborations (UIC) (Balconi, 2004; Belderbos \& Carree, 2004; Mansfield, 1996)

- collaboration with suppliers (Un et al., 2010)

- external acquisition of knowledge (Fey \& Birkinshaw, 2005; Huang \& Rice, 2009; Inauen \& Schenker-Wicki, 2011)

- selling of a knowledge asset (Chiaroni et al., 2010)

- strategic alliances for technological activities (Belderbos et al. , 2010)

- collaboration with government (Grimpe \& Kaiser, 2010; Hwang \& Lee, 2010; Laursen \& Salter, 2006)

- licensing out and in (Tsai \& Chang, 2008)

- inbound acquisition of firms/technology (Vanhaverbeke et al., 2002)

- external commercialisation of technology (Kutvonen, 2011)

- co-creation of patents (Lin et al., 2012)

- R\&D alliance (Fey \& Birkinshaw, 2005; Lin \& Wu, 2010)

- manufacturing alliance (Dahlander \& Gann, 2010; Faems et al., 2010; Suh \& Kim, 2012).

to risk as compared to others as well as to present the types of collaboration of these firms with other firms in their internal and external network as an effort towards openness.

\section{Methodology and Analysis}

The sample represents the 31 manufacturing-based firms listed in the National Stock Exchange of India (NSE) under the index called the "Nifty Fifty"; the 19 non-manufacturing firms in the index were removed from the sample. The reason for selecting the sample from this index was that the resulting organizations were all: i) major companies in the manufacturing sector, ii) listed in the same stock exchange, and iii) large 


\section{Open Innovation in Indian Organizations: Types of Collaboration}

\section{Shiv S. Tripathi}

organizations having an average free-float market capitalization of INR 17,011.58 crores (approx. $\$ 3.3$ billion CAD as of April 2016).

For each of the 31 targeted firms, information about their collaborations was collected from: i) their annual reports for the year 2014-15, ii) information on their websites; and iii) data available at the national stock exchange. For open innovation, researchers have suggested a K-10 or 10-year data model to study the phenomenon in a particular company (Nadkarni \& Narayanan, 2007); however, we determined that one year of data would be sufficient for our purposes because the objective was to identify the present state of collaboration and not to measure the impact or performance of open innovation initiatives of the targeted firms. The approach of selecting firms listed on a stock exchange and analyzing data based on their annual reports to study open innovation was also used by Mazzola and colleagues (2012).

Following Dahlander and Gann (2010), each firm's collaborative activities were classified into one of four categories of open innovation: i) inbound acquiring, ii) inbound sourcing, iii) outbound revealing, or iv) outbound selling. The findings and key insights for each category are described in the subsections that follow; Table 1 provides an overview of the categories of open innovation observed across the 12 industries.

\section{Inbound acquiring}

Among the 12 industries in the sample, nine were selfsufficient in their R\&D. Only three industries -automobiles, paints, and pharmaceuticals - and precisely, only one company each from each industry, followed the inbound acquisition route for collaboration. In these three industries, the primary purpose of such collaborations was to gain access to proprietary technology that would benefit the acquiring company and effectively block the entry of other players into the market.

Key insights for each industry were as follows:

- Automobiles and automobile components: Only one transnational automobile components firm continuously looks outwards to acquire new technologies and companies. The other five go through a collaborative route, such as a joint venture or strategic alliance.

- Paints: The sampled company from this industry has a technology council at the senior management level that continuously looks for new technologies and companies from any part of the world.
- Pharmaceuticals: One company out of the four pharmaceutical companies in the sample was involved in buying-in a majority stake in a precision pharmaceutical company (a leading respiratory device manufacturer) to become self-reliant through backward integration.

\section{Inbound sourcing}

Thirty out of 31 firms were engaged in an activity related to the sourcing of external knowledge, although the types differed across various industries. The key features were large conglomerates that had or wanted to have a dedicated facility or firm looking after the transfer of inbound and outbound knowledge. Some were so particular about it that they had a board-level committee to take such decisions. The activities and actions (or planned actions) suggested that almost every firm realized that they need to collaborate with the external world, but that it might just be limited to sourcing external knowledge for the time being.

Key insights for each industry were as follows:

- Automobiles and components: Six companies in the list deploy various forms of collaboration with suppliers, including global R\&D centres that are open to automotive alliances as well as suppliers. Through such collaborations, one company experienced a $100 \%$ increase in the number of patents they filed. There are also clear mechanisms for idea generation from within the organization as well as from the suppliers. Three firms aspired to have world-class centres for R\&D and global innovation, out of which two have already achieved it and the third one is going to establish it in the United Kingdom by 2017.

- Oil and gas: There are three public sector and one private sector organizations in this group. Except for one public sector organization, which has yet to open up internally, the remaining three have specific programs to exploit external knowledge through alliances, joint ventures for upstream technologies, and programs to enable employees to go beyond their job descriptions and try something new and innovative. They bring in the research expertise of universities involved in all kinds of hydrocarbons research.

- Pharmaceuticals: Out of four companies in the list, all except one are globally active. Two collaborate in various ways through subsidiaries or joint ventures in different countries, while the third one has established itself as a specialty pharmaceutical company and conducts various "reach out" activities only in that partic- 


\section{Open Innovation in Indian Organizations: Types of Collaboration}

\section{Shiv S. Tripathi}

Table 1. Categories of open innovation observed across 12 industries representing the 31 sampled Indian firms

\begin{tabular}{|c|c|c|c|c|}
\hline \multirow{2}{*}{$\begin{array}{l}\text { Industry } \\
\text { (Number of firms) }\end{array}$} & \multicolumn{2}{|c|}{ Outside-In Open Innovation } & \multicolumn{2}{|c|}{ Inside-Out Open Innovation } \\
\hline & Inbound Acquiring & Inbound Sourcing & Outbound Revealing & Outbound Selling \\
\hline $\begin{array}{l}\text { Automobiles and } \\
\text { components (6) }\end{array}$ & $\begin{array}{l}\text { - Technology buy-in } \\
\text { - Company buy-in }\end{array}$ & $\begin{array}{l}\text { - Technological know-how } \\
\text { arrangements } \\
\text { - Joint ventures with } \\
\text { suppliers } \\
\text { - Open R\&D centres } \\
\text { - Collaboration with auto } \\
\text { alliances } \\
\text { - Idea contests for staff }\end{array}$ & $\begin{array}{l}\text { - Rescarch projects } \\
\text { for universities } \\
\text { - Immersion } \\
\text { programs } \\
\text { - Co-creation with } \\
\text { academic } \\
\text { partners }\end{array}$ & \\
\hline Oil and gas (4) & & $\begin{array}{l}\text { - Joint ventures } \\
\text { - Global alliances for } \\
\text { technology }\end{array}$ & $\begin{array}{l}\text { - Industry- } \\
\text { academia } \\
\text { partnership } \\
\text { - Opening facilities } \\
\text { for entrepreneurs }\end{array}$ & \\
\hline Pharmaceuticals (4) & $\begin{array}{l}\text { - Majority stake } \\
\text { buy-in }\end{array}$ & $\begin{array}{l}\text { - Collaboration for special } \\
\text { purposes with other } \\
\text { global players } \\
\text { - Specialized subsidiaries } \\
\text { in various countries }\end{array}$ & $\begin{array}{l}\text { - Innovation centres } \\
\text { in universities }\end{array}$ & \\
\hline Cement (3) & & $\begin{array}{l}\text { - Technology sourcing by } \\
\text { paying a license fee } \\
\text { - Partnership with local } \\
\text { bodies } \\
\text { - Partnerships with non- } \\
\text { governmental } \\
\text { organizations } \\
\text { - Partnerships with other } \\
\text { institutions }\end{array}$ & & \\
\hline Power (3) & & $\begin{array}{l}\text { - Joint ventures } \\
\text { - Collaboration through } \\
\text { holding companies } \\
\text { - Partnership with local } \\
\text { bodies and governments }\end{array}$ & & \\
\hline Steel (3) & & $\begin{array}{l}\text { - An independent business } \\
\text { unit to take care of } \\
\text { innovation activities for } \\
\text { all the group companies }\end{array}$ & $\begin{array}{l}\text { - Industry- } \\
\text { academia } \\
\text { partnership }\end{array}$ & $\begin{array}{l}\text { - Providing turnkey } \\
\text { solutions for } \\
\text { establishing steel } \\
\text { plants }\end{array}$ \\
\hline
\end{tabular}




\section{Open Innovation in Indian Organizations: Types of Collaboration}

\section{Shiv S. Tripathi}

Table 1 (cont.). Categories of open innovation observed across 12 industries representing the 31 sampled Indian firms

\begin{tabular}{|c|c|c|c|c|}
\hline \multirow{2}{*}{$\begin{array}{l}\text { Industry } \\
\text { (Number of firms) }\end{array}$} & \multicolumn{2}{|c|}{ Outside-In Open Innovation } & \multicolumn{2}{|c|}{ Inside-Out Open Innovation } \\
\hline & Inbound Acquiring & Inbound Sourcing & Outbound Revealing & Outbound Selling \\
\hline $\begin{array}{l}\text { Fast-moving } \\
\text { consumer goods (2) }\end{array}$ & & $\begin{array}{l}\text { - Co-creation with } \\
\text { suppliers } \\
\text { - Co-creation with } \\
\text { customers } \\
\text { - Innovation networks } \\
\text { - Collaboration with } \\
\text { stakeholders such as } \\
\text { municipalities and } \\
\text { governments } \\
\text { - Open innovation teams }\end{array}$ & & \\
\hline $\begin{array}{l}\text { Mining and minerals } \\
\text { (2) }\end{array}$ & & $\begin{array}{l}\text { - Joint ventures } \\
\text { - Technical collaboration } \\
\text { - Co-discovery } \\
\text { mechanisms }\end{array}$ & & \\
\hline Heavy electricals ( 1 ) & & & $\begin{array}{l}\text { - Co-creation with } \\
\text { competitors }\end{array}$ & $\begin{array}{l}\text { - Sale of turnkey } \\
\text { expertise to other } \\
\text { companies }\end{array}$ \\
\hline Heavy machinery (1) & & $\begin{array}{l}\text { - Common group company } \\
\text { to look after innovation } \\
\text { - Technical and cross- } \\
\text { functional collaboration } \\
\text { with Indian corporations } \\
\text { - Technical and cross- } \\
\text { functional collaboration } \\
\text { with foreign corporations }\end{array}$ & & \\
\hline Paints (1) & $\begin{array}{l}\text { - Technology buy-in } \\
\text { - Company buy-in }\end{array}$ & $\begin{array}{l}\text { - Joint ventures for testing } \\
\text { and commercialization } \\
\text { - Sourcing of technology }\end{array}$ & & \\
\hline Textiles (1) & & $\begin{array}{l}\text { - Multidisciplinary teams } \\
\text { for collaboration with } \\
\text { other parties }\end{array}$ & & \\
\hline
\end{tabular}




\section{Open Innovation in Indian Organizations: Types of Collaboration}

\section{Shiv S. Tripathi}

ular domain. The two companies having subsidiaries and joint ventures abroad have seen a continuous rise in the $R \& D$ intensity through their full-fledged $R \& D$ centres and now are well known companies in the global pharmaceutical industry.

- Cement: Out of three companies in this group, one was paying a licensing fee to another company for technological know-how. The other two had a number of innovative products and their expenditures on $R \& D$ were going up in absolute terms while R\&D intensity was coming down.

- Power: Being a regulatory industry, all three firms in this group entered into legal collaborative agreements with all partners whether through the joint venture route in India or outside, or they collaborated through their holding companies. Although they enter into such agreements for innovation, they often end up conducting activities relating to improving operational efficiency rather than focused specifically on innovation.

- Steel: Out of three companies in this group, one already has a dedicated company looking after multidisciplinary team association, new product and technology development, and innovation. The second company is going to establish a large innovation centre in the United Kingdom that will institutionalize innovation and give it a systematic push even though a number of innovations have already generated a revenue stream for the organization. The third company has an innovation task force and a technology innovation advisory committee at the top management level that helps institutionalize innovation by showing commitment of the management and takes care of all related inbound and outbound processes.

- Fast-moving consumer goods: There are two companies in this group: one is national and the other is multinational. Both of them interact with end users frequently - much more often than any other industry in this study. Though both of them have have programs to collaborate with their partners, the multinational has established innovation networks at the country level and has initiated the process of open innovation by establishing a dedicated teams in its R\&D departments. The national company has identified a niche in life sciences technology and has developed a collaborative network with various regulatory stakeholders so that they are able to launch new products, but the major emphasis is on sales.
- Mining and minerals: There are two companies in this group and both belong to the public sector. One is active in all kinds of joint ventures and Indian and foreign collaborations for exploration and technology including with organizations in the United States, the European Union, and Australia. The other company has limited scope in terms of operations; they have confined themselves to India only and do not appear to be seeking any collaboration or knowledge transfer.

- Heavy machinery: The only company represented in the list from this industry leverages a lead group company that has the responsibility to guide and look after innovation efforts by various group companies, including this one. The primary focus is on technologyled innovation. It collaborates with various companies, essentially under technical collaboration or partnership.

- Paints: The only company listed in the index belonging to this industry is quite active in terms of joint ventures and collaboration. They are able to test new products and technologies in one country and commercialize them in another country. Their R\&D intensity as well as R\&D expenditure is also continuously going up.

- Textiles: Part of a large diversified group, the company has a lead sister concern that looks after innovation and collaboration activities for the group, including this company. The company has formed multidisciplinary teams for in-house innovation and to look for outside opportunities.

\section{Outbound revealing}

Evidence of outbound revealing was limited to industries that require a high degree of coordination among the upstream and downstream business partners. This included automobiles, heavy electricals, oil and gas, pharmaceuticals, and steel. These all were large integrated firms where cost cutting or possessing propriety knowledge was a major concern. The indicators of openness in such firms are industry-academia partnerships and co-creation initiatives. However, the purpose of collaborating with other organizations varied across industries. In industries such as steel and automobiles, the purpose was to cut product-development costs, whereas in an industry such as pharmaceuticals, collaboration was based on a specific technology that would give the companies a strategic advantage. The firms here were also not very much interested in licensing out their technologies. 


\section{Open Innovation in Indian Organizations: Types of Collaboration}

\section{Shiv S. Tripathi}

Key insights for each industry were as follows:

- Automobiles and components: Three out of six firms in this industry do not have any significant revelation for the outside world; the remaining three are quite open to industry-academia partnerships. These latter three companies work together with universities and open their labs and R\&D departments along with suppliers for developing innovative products.

- Oil and gas: Three out of four firms in the industry engage in industry-academia partnerships with the leading universities such as Indian Institutes of

Technology. The only private firm among these three allows entrepreneurs to join their global innovation forum for mutual benefits.

- Pharmaceuticals: Only one company has established innovation centres in universities outside India for developing innovative products.

- Steel: Only one firm out of three provides industryacademia partnership by opening up their facilities for faculty and students.

- Heavy electricals: The one firm in this industry works in tandem with its competitors (although not directly) to co-create new products and create win-win situations.

\section{Outbound selling}

In this category, only two companies - one company belonging to heavy electricals industry and one belonging to the steel industry - were selling their capabilities to outside parties. Both firms were outbound selling through their subsidiaries as a new revenue stream, spinning it out and earning revenue that helps in writing off the expenditure in $R \& D$. They might have started sharing knowledge with other firms much earlier and formed these subsidiaries once the volume of this inside-out knowledge transfer became large.

Key insights for each industry were as follows:

- Steel: Of the three steel firms in the index, the largest is an integrated steel manufacturer that provides turnkey solutions to establish small specialized steel plants through a different subsidiary. This subsidiary provides manufacturing knowledge consultancy services to other companies.

- Heavy electricals: The only company representing this industry in the index provides turnkey expertise to other companies and earns revenue. Although some evid- ence was found for outbound selling to competitors and suppliers, such activities are accomplished by a different subsidiary of the same group and not by the company that is part of this sample.

\section{Discussion}

The Indian manufacturing-based firms in this study follow inbound sourcing as the primary method to go open and collaborate with other firms in their networks. Thereafter, they reach out to academia and engaged through outbound revealing. The inbound acquiring of capabilities or technology and outbound selling come later. From the pace of growth of these four activities of open innovation, it can be concluded that a majority of Indian firms are following an outsidein type of open innovation as per their requirement. They understand the need to reach out to related and unrelated partners to bridge the gaps in their technology or capabilities or to develop new ones. However, few companies in this study have gone into the revealing mode. Companies that are markets leaders, have expertise in a domain or technology expertise, are in capital-intensive industries, have a global experience curve have started adopting the revelation mode or inviting outsiders for development of products with or for them.

If we rank the industries based on the number of types of collaboration in the overall category of outside-in innovation, we see that automobiles and components, paints, and fast-moving consumer goods occupy the first, second, and third place, respectively. These industries primarily serve consumer markets, and may therefore be more inclined to seek input from outsiders, including consumers. These three industries use a greater variety of collaboration forms to reach out and gain vital inputs in term of technology and capabilities for developing new products. Barring heavy electricals, all industries selected in the sample show evidence of collaboration of different types for outside-in innovation. On the other hand, inside-out innovation, which generally comes after a company has gained the advantages of outside-in innovation, is more common in automobiles and components, oil and gas, steel, heavy electricals, pharmaceuticals, and mining and minerals. Therefore, these industries can be considered more open than the others in the sense that they make use of their internal and external network of partners. The industries where inside-out is still absent are cement, fastmoving consumer goods, heavy machinery, paints, power, and textiles. Companies in these industries may still be protective and reluctant to share capabilities 


\section{Open Innovation in Indian Organizations: Types of Collaboration}

\section{Shiv S. Tripathi}

and resources with the outside world. Although the government has provided incentives to openness including generous limits of outward foreign direct investment, they may still be reluctant to take risks in this way. One reason might be a tendency towards closed organizational cultures in these industries, although further study is required to understand the motivations of the firms in this study to open up or remain closed.

\section{Conclusion}

The research gives an idea about the types of open innovation used in large firms in India, which is a fastgrowing emerging market. The limited types of collaboration at both the extremes of inbound acquiring and outbound selling shows that the manufacturing-based firms are cautious before taking a plunge into an acquisition or selling out a wing as the returns from such a move might not be immediate and, at the same time, the risk is high. The types of collaboration that are existing in various industries give pointers to various firms trying to do business in India or partner with Indian firms. It is also observed that firms that have global operations or global markets for their products tend to be more open through their subsidiaries if not through their parent organization based in India. A company is able to cushion the risk and exposure to intellectual property rights issues by putting only one arm forward in the form of a subsidiary located in a foreign country. It also gives an indication of the need for them to open up and the types of collaborations they are making with other parties.

The nature of business prompts companies to be more open, as seen in the multitude of suppliers required in the automobile industry or in industries requiring long gestation and large investment projects, as seen in the oil and gas industry. Chain reactions were also visible: if one company establishes a dedicated innovation centre in any part of the world, other companies in the same industry are motivated to take more risks in opening up their boundaries for other firms by way of collaborations. They appear to feel a bit more secure if the acid test has already been taken by the first company.

This research adds to the literature on how emerging market firms adopt open innovation, when due to will and when due to compulsion. It also presents a comparative evaluation of various industries, revealing which of them are more open as compared to others, which forms of collaboration are common across certain industries, and which forms of collaborations are still unique to a particular industry.
Future studies should consider the age and stage of the firm in the local market and their effects on a firm's open innovation ambition. Similarly, it would help to compare open innovation practices between emerging market firms and emerged or developed market firms. By using age, size, geographical spread, nature, and complexity of the firm as control variables, a statistical analysis can be done to study unique types of open innovation used by these firms. Similarly, reasons may be explored as to why some companies are more open in an industry and why others are not.

\section{About the Author}

Shiv S. Tripathi is an Assistant Professor of Strategic Management at the Management Development Institute in Gurgaon, India. He holds a PhD degree from Vinod Gupta School of Management at the Indian Institute of Technology, Kharagpur. He has published papers in the area of product and service innovations, growth strategies, and innovations in large organizations. He has presented papers at national and international conferences organized by the Indian Institutes of Management, Indian Schools of Business, and the Strategic Management Society. His current research interests include open innovation, ambidexterity, and innovation in emerging markets. He is a member of the Academy of Management, the International Society of Professional Innovation Management, and the Strategic Management Society. He is presently writing a book on innovation strategy.

\section{References}

Badani, J. 2011. Open Innovation in India: Are Indian Companies Ready for Open Innovation? Tech Monitor, July-August: 60-61.

Balconi, M. 2004. Networks of Inventors and the Role of Academia: An Exploration of Italian Patent Data. Research Policy, 33(1): 127-145. http://dx.doi.org/10.1016/S0048-7333(03)00108-2

Balderbos, R., \& Carree, M. 2004. Cooperative R\&D and Firm Performance. Paper presented at the DRUID Summer Conference, Copenhagen, June 14-16, 2004.

Belderbos, R., Faems, D., Leten, B., \& Van Looy, B. 2010. Technological Activities and Their Impact on the Financial Performance of the Firm: Exploitation and Exploration within and between Firms. Journal of Product Innovation Management, 27(6): 869-882.

http://dx.doi.org/10.1111/j.1540-5885.2010.00757.x 


\section{Open Innovation in Indian Organizations: Types of Collaboration}

\section{Shiv S. Tripathi}

Chesbrough, H. 2003. Open Innovation: The New Imperative of Creating and Profiting from Technology. Boston, MA: Harvard Business School Press.

Chiaroni, D., Chisea, V., \& Frattini, F. 2010. Un-Ravelling the Process from Closed to Open Innovation: Evidence from Mature, AssetIntensive Industries. R\&D Management, 40(3): 222-245. http://dx.doi.org/10.1111/j.1467-9310.2010.00589.x

Dahlander, L., \& Gann, D. M. 2010. How Open Is Innovation? Research Policy, 39(6): 699-709. http://dx.doi.org/10.1016/j.respol.2010.01.013

Faems, D., de Visser, M. Andries, P., \& Van Looy, B. 2010. Technology Alliance Portfolios and Financial Performance: Value-Enhancing and Cost-Increasing Effects of Open Innovation. Journal of Product Innovation Management, 27(6): 785-796. http://dx.doi.org/10.1111/j.1540-5885.2010.00752.x

Fey, C., \& Birkinshaw, J. 2005. External Sources of Knowledge, Governance Mode and R\&D Performance. Journal of Management, 31(4): 597-621. http://dx.doi.org/10.1177/0149206304272346

Gassmann, O., \& Enkel, E. 2004. Toward a Theory of Open Innovation: Three Core Process Archtypes. Paper presented at the R\&D Management Conference, Lisbon, July 6, 2004.

Grimpe, C., \& Kaiser, U. 2010. Balancing Internal and External Knowledge Acquisition: The Gains and Pains from R\&D Outsourcing. Journal of Management Studies, 47(8): 1483-1509. http://dx.doi.org/10.1111/j.1467-6486.2010.00946.x

Huang, F., \& Rice, J. 2009. The Role of Absorptive Capacity in Facilitating "Open Innovation" Outcomes: A Study of Australian SMEs in the Manufacturing Sector. International Journal of Innovation Management, 13(2): 201-220.

http://dx.doi.org/10.1142/S1363919609002261

Hwang, J., \& Lee, Y. 2010. External Knowledge Search, Innovative Performance and Productivity in the Korean ICT Sector. Telecommunication Policy, 34(10): 562-571. http://dx.doi.org/10.1016/j.telpol.2010.04.004

Inauen, M., \& Schenker-Wicki, A. 2011. The Impact of Outside-In Open Innovation on Open Innovation Performance. European Journal of Innovation Management, 14(4): 496-520. http://dx.doi.org/10.1108/14601061111174934

Kutvonen, A. 2011. Strategic Application of Outbound Open Innovation. European Journal of Innovation Management, 14(4): 460-474

http://dx.doi.org/10.1108/14601061111174916
Laursen , K., \& Salter, A. 2006. Open for Innovation: The Role of Openness in Explaining Innovation Performance among U.K. Manufacturing Firms. Strategic Management Journal, 27(2): 131-150.

http://dx.doi.org/10.1002/smj.507

Lin, B.-W., \& Wu, C. H. 2010. How Does Knowledge Depth Moderate the Performance of Internal and External Knowledge Sourcing Strategies? Technovation, 30(11/12): 582-589.

http://dx.doi.org/10.1016/j.technovation.2010.07.001

Lin, C., Wu, Y.-J., Chang, C., Wang, W., \& Lee, C.-Y. 2012. The Alliance Innovation Performance of $R \& D$ Alliances: The Absorptive Capacity Perspective. Technovation, 32(5): 282-292.

http://dx.doi.org/10.1016/j.technovation.2012.01.004

Mansfield, E. 1996. The Modern University: Contributor to Industrial Innovation and Recipient of Industrial R\&D Support. Research Policy, 25(7): 1047-1058. http://dx.doi.org/10.1016/S0048-7333(96)00893-1

Mazzola, E., Manfredi, B., \& Giovanni, P. 2012. The Effect of Inbound, Outbound and Coupled Innovation on Performance. Paper presented at the XXIII ISPIM Innovation Conference, Barcelona, Spain, June 17-20, 2012.

Nadkarni, S., \& Narayanan, V.K. 2007. Strategic Schemas, Strategic Flexibility and Firm Performance: The Moderating Role of Industry Clockspeed. Strategic Management Journal, 28: 243-270. http://dx.doi.org/10.1002/smj.576

Suh, Y., \& Kim, M.-S. 2012. Effects of SME Collaboration on R\&D in the Service Sector in Open Innovation. Innovation: Management, Policy \& Practice, 14(3): 349-362. http://dx.doi.org/10.5172/impp.2012.14.3.349

Tsai, K.-H., \& Chang, H.-C. 2008. The Contingent Value of Inward Technology Licensing on the Performance of Small HighTechnology Firms. Emerging Markets Finance and Trade, 44(4): 88-98.

http://dx.doi.org/10.2753/REE1540-496X440407

Un, C. A., Cuervo-Cazurra, A., \& Asakawa, K. 2010. R\&D Collaborations and Product Innovation. Journal of Product Innovation Management, 27(5): 673-689. http://dx.doi.org/10.1111/j.1540-5885.2010.00744.x

Vanhaverbeke, W., Duysters, G., \& Noorderhaven, N. 2002. External Technology Sourcing through Alliances or Acquisitions: An Analysis of the Application-Specific Integrated Circuits Industry. Organization Science, 13(6): 714-733.

http://dx.doi.org/10.1287/orsc.13.6.714.496

Citation: Tripathi, S. S. 2016. Open Innovation in Indian Organizations: Types of Collaboration. Technology Innovation Management Review, 6(5): 15-23. http://timreview.ca/article/987 